\title{
Occupation and malignant lymphoma: a population based case control study in Germany
}

\author{
B Mester, A Nieters, E Deeg, G Elsner, N Becker, A Seidler
}

Occup Environ Med 2006;63:17-26. doi: 10.1136/oem.2005.020453

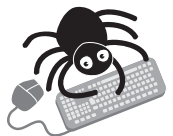

Additional data are available on the OEM website (www.occenvmed.com/ supplemental)

See end of article for authors' affiliations

.....................

Correspondence to: PD Dr A Seidler, MPH, Institut für Arbeitsmedizin Johann Wolfgang GoetheUniversität, Theodor-SternKai 7, D-60590 Frankfurt/ Main, Germany; a.seidler@

em.uni-frankfurt.de

Accepted 28 July 2005

\begin{abstract}
Aims: To identify occupations suspected to be associated with malignant lymphoma and to generate new hypotheses about occupational risks in a multicentre, population based case control study.

Methods: Male and female patients with malignant lymphoma $(n=710)$ aged $18-80$ years of age were prospectively recruited in six study regions in Germany. For each newly recruited lymphoma case, a sex, region, and age matched control was drawn from the population registers. Odds ratios and $95 \%$ confidence intervals for major occupations and industries were calculated using conditional logistic regression analysis, adjusted for smoking (in pack-years) and alcohol consumption. Patients with specific lymphoma subentities were additionally compared with the entire control group using unconditional logistic regression analysis.

Results: The following economic/industrial sectors were positively associated with lymphoma: food products, beverages, tobacco; paper products, publishing and printing; and metals. Chemicals; real estate, renting, and business activities were negatively associated with lymphoma diagnosis. The authors observed an increased overall lymphoma risk among architects; maids; farmers; glass formers; and construction workers. Shoemaking and leather goods making was negatively associated with the lymphoma diagnosis (although based on small numbers). In the occupational group analysis of lymphoma subentities, Hodgkin's lymphoma was significantly associated only with rubber and plastic products making; diffuse large B cell lymphoma risk was considerably increased among metal processors; follicular lymphoma showed highly significant risk increases for several occupational groups (medical, dental, and veterinary workers; sales workers; machinery fitters; and electrical fitters); and multiple myeloma showed a particularly pronounced risk increase for farmers as well as for agriculture and animal husbandry workers. Conclusions: The results partly confirm previously defined occupational risks. Occupational risk factors for follicular lymphomas might differ from the overall risk factors for malignant lymphoma.
\end{abstract}

more appropriate for aetiological research than earlier classifications.

\section{MATERIALS AND METHODS \\ Study population}

The study design has been described in detail in previous publications. ${ }^{33}{ }^{34}$ Briefly, the study was conducted under the leadership of the German Cancer Research Center (DKFZ) in six defined regions in Germany: Ludwigshafen/Upper Palatinate, Heidelberg/Rhine-Neckar-County, Würzburg/ Lower Frankonia, Hamburg, Bielefeld/Guetersloh, and Munich. In the mentioned study areas, all hospital and ambulatory physicians involved in the diagnosis and therapy of malignant lymphoma were asked to identify prospectively all patients aged 18-80 years with newly diagnosed lymphoma (NHL and Hodgkin's lymphoma). Lymphoma patients were required to be resident in the study area and to be familiar with the German language.

All cases were classified according to the new WHO classification. ${ }^{31}{ }^{32}$ The WHO classification of lymphoma defines subentities which are based, to a larger extent than previous classifications, on their natural history and biological features. Of 710 participating lymphoma patients (participation rate, 87.4\%), 115 suffered from Hodgkin lymphoma, 554 suffered from B-non-Hodgkin's lymphoma, 35 from T-non-Hodgkin's lymphoma, one suffered from combined B-non-Hodgkin's lymphoma and Hodgkin's lymphoma, and

Abbreviations: CLL, chronic lymphocytic leukaemia; JEM, job exposure matrix; NHL, non-Hodgkin's lymphoma; SLL, small lymphocytic lymphoma 
five from other lymphoma. According to the WHO classification, B-non-Hodgkin's lymphoma were further subdivided into the following subentities (only subentities with $\mathrm{n}>30$ cases are mentioned): diffuse large B-cell lymphoma $(\mathrm{n}=158)$; follicular lymphoma $(\mathrm{n}=92)$; chronic lymphocytic leukaemia (CLL)/small lymphocytic lymphoma (SLL) $(\mathrm{n}=104)$; plasma cell myeloma (plasmacytoma) $(\mathrm{n}=76)$; and marginal zone B-cell lymphoma $(\mathrm{n}=38)$.

For each newly recruited lymphoma case, a sex, region, and age matched (plus or minus 1 year of birth) population control was drawn from the population registration office. Control subjects that were not familiar with the German language were excluded from the study. For each participant who had to be excluded from the study or rejected participation, the recruitment procedure was repeated. Among population controls the participation rate was $44.3 \%$. Of the non-participants, $24.9 \%$ could not be traced, $51 \%$ refused to participate due to lack of interest, and $11.5 \%$ due to health problems. The remaining $12.4 \%$ mentioned other reasons for non-participation. A total of 710 case control pairs were included in the analysis.

\section{Data collection}

In a face to face interview, intensively trained interviewers elicited detailed information about the medical history (including medication), lifestyle (including smoking, alcohol consumption, and leisure time activities), and occupation. Three cases could not be interviewed and four additional cases lacked the information regarding the occupational history. All residual subjects were personally interviewed. The interviewers documented a complete occupational history, including every occupational period that lasted at least one year. For every job held, information was elicited about the start and the end of the job phase, job title, industry, and specific job tasks. Study subjects having held potentially hazardous jobs were additionally asked to reply to job taskspecific supplementary questions. For this purpose, a set of 14 job task-specific supplementary questionnaires had been developed following Bolm-Audorff et al. ${ }^{35}$

\section{Exposure assessment}

Job titles and branches of industry were coded blind to the case control status by two experienced coders in the Frankfurt Institute for Occupational Medicine, according to the International Standard Classification of Occupations (ISCO-68) and the Statistical Classification of Economic Activities in the European Community (NACE Rev 1). These classifications, based on five and four digits, respectively, increase the specificity of each occupation/industry with increasing number of digits (for example, ISCO code 92: printers and related workers, and ISCO 92155: photo-typesetting machine operator).

\section{Characteristics of cases and control subjects}

The characteristics of the cases with lymphoma and control subjects are available online (see http://www.occenvmed. com/supplemental). The mean (standard deviation) age of cases with any lymphoma $(\mathrm{n}=710)$ was 56.1 (SD 16.3) years; of cases having Hodgkin's lymphoma $(\mathrm{n}=116), 38.8$ (SD 15.9) years, of cases having B-nonHodgkin's lymphoma $(\mathrm{n}=554) 60.2$ (SD 13.6) years; and of cases having T non-Hodgkin's lymphoma $(\mathrm{n}=35) 50.6$ ( SD 17.0 ) years. Of the 710 case control pairs, $55 \%$ were male and $45 \%$ were female. The average number of different occupations (held for at least one year) was 2.4 for lymphoma cases as well as for control subjects. The average count of different industries was 2.9 for lymphoma cases as well as for control subjects.

\section{Data analysis}

Major occupations and industries were a priori formed on the basis of the two digit job title codes and the three digit industry codes, respectively. Risk by job duration was calculated for major occupations and industries using two categories of duration ( $1-10$ years, more than 10 years). Those who were never employed in the particular occupation or industry were included in the reference category. In the analysis of occupational groups, only subjects having worked in non-exposed white collar works as main occupation were included in the reference category. Missing values were analysed as a separate category (results not shown here).

At first, we analysed the relation between industrial as well as occupational groups and lymphomas as a whole $(\mathrm{n}=710)$. Odds ratios (OR) and 95\% confidence intervals (CI) were calculated using conditional logistic regression analysis, adjusted for smoking (in pack-years) and alcohol consumption. Lymphomas comprise a multitude of pathogenetically different subentities with little information to what extent they are also aetiologically different or share common environmental factors. Secondly, we calculated odds ratios for the more frequent lymphoma subentities (with $n>30$ cases; please see under Study population). To increase the statistical power, patients with these lymphoma subentities were compared separately with the entire control group $(\mathrm{n}=710)$ using unconditional logistic regression analysis. Covariates included in this unmatched analysis were age (as a continuous variable), sex, region, smoking (in pack-years), and alcohol consumption. To exclude potentially "noncausal" occupational exposures from analysis, in an additional latency analysis, only exposures up to 10 years before the lymphoma diagnosis were considered.

\section{RESULTS}

Table 1 presents odds ratios and $95 \%$ confidence intervals (CI) for the association between economic or industrial sectors and the entire case group $(n=710$ lymphoma patients); only the results for industrial groups with at least five lymphoma cases are reported. Significantly increased risks can be seen for the sectors food products, beverages, tobacco (NACE 150-160) and pulp paper, paper products, publishing and printing (NACE 210-223). In the subentity analysis, for the sector "food products, beverages, tobacco (NACE 150-160) particularly strongly increased odds ratios can be seen for follicular lymphomas and CLL (table 2), while for other subentities the numbers were too small to provide conclusive results. For pulp papers, paper products, publishing and printing (NACE 210-223) the odds ratios were significantly increased for multiple myeloma as well as $\mathrm{T}$ cell and NK cell NHL.

For the sector basic metals and fabricated metal products (NACE 270-287) an overall null result covers a strongly increased odds ratio among long term exposed subjects; however, based on small numbers. In the subentity analysis significant increases are found for Hodgkin's lymphoma.

Significantly decreased odds ratios occur for the sectors chemicals, chemical products, and man-made fibres (NACE 240-247) and real estate, renting, business activities (NACE 700-748) with consistent but non-significant decreases for short term and long term exposures. In the subentity analysis, the negative association with these industrial sectors looses its statistical significance.

The top level evaluation (all lymphoma combined) might mask associations between specific factors and individual subentities. Therefore, in table 2 all significant associations between industrial sectors and lymphoma subentities are reported (except for B-NHL in total, which mainly reflect the risks of all lymphomas combined). Several associations with economic sectors are found which are statistically significant 
Table 1 Odds ratios and $95 \%$ confidence limits for economic/industrial sectors in relation to lymphomas ( $n=710$ matched pairs; only sectors with at least five exposed cases are presented)

\begin{tabular}{|c|c|c|c|c|c|c|c|c|c|c|c|}
\hline \multirow[b]{2}{*}{$\begin{array}{l}\text { NACE } \\
\operatorname{Rev} 1\end{array}$} & \multirow[b]{2}{*}{ Industry } & \multicolumn{4}{|c|}{$1-10$ years } & \multicolumn{4}{|c|}{$>10$ years } & \multicolumn{2}{|l|}{ All } \\
\hline & & Cases & $s$ Controls & Adj $O R^{*}$ & $95 \% \mathrm{Cl}$ & Cases & Controls & $\begin{array}{l}\text { Adi } \\
\text { OR }^{*}\end{array}$ & $95 \% \mathrm{Cl}$ & $\begin{array}{l}\text { Adj } \\
\text { OR }^{*}\end{array}$ & $95 \% \mathrm{Cl}$ \\
\hline 010-020 & Agriculture, hunting, forestry & 59 & 63 & 1.0 & $0.6-1.4$ & 26 & 18 & 1.5 & $0.8-2.8$ & 1.1 & $0.8-1.6$ \\
\hline $100-145$ & Mining and quarrying & 5 & 5 & 0.9 & $0.2-3.8$ & - & 1 & - & - & 0.7 & $0.2-2.7$ \\
\hline $150-160$ & Food products, beverages, tobacco & 44 & 30 & 1.5 & $0.9-2.5$ & 27 & 15 & 1.9 & $1.0-3.8$ & $1.7 \dagger$ & $1.1-2.5$ \\
\hline $170-183$ & Textiles, textile products & 37 & 39 & 0.9 & $0.6-1.6$ & 15 & 19 & 0.8 & $0.4-1.7$ & 0.9 & $0.6-1.4$ \\
\hline 190-193 & Leather, leather products & 7 & 18 & $0.4 \dagger$ & $0.1-0.9$ & 7 & 2 & 3.4 & $0.7-16.9$ & 0.7 & $0.3-1.4$ \\
\hline 200-205 & Wood, wood products & 10 & 11 & 0.7 & $0.3-1.8$ & 3 & 4 & 0.7 & $0.1-3.1$ & 0.7 & $0.3-1.6$ \\
\hline $210-223$ & Pulp paper, paper products, publishing and printing & 24 & 14 & 1.7 & $0.9-3.4$ & 19 & 12 & 1.7 & $0.8-3.6$ & $1.7+$ & $1.0-2.8$ \\
\hline $230-233$ & Coke, refined petroleum products, nuclear fuel & 3 & 2 & 1.3 & $0.2-7.9$ & 3 & 1 & 3.5 & $0.4-34.6$ & 2.0 & $0.5-8.1$ \\
\hline $240-247$ & Chemicals, chemical products, and man-made fibres & s 26 & 35 & 0.6 & $0.3-1.1$ & 34 & 47 & 0.7 & $0.4-1.1$ & $0.6+$ & $0.4-0.9$ \\
\hline $250-252$ & Rubber, plastic products & 14 & 10 & 1.4 & $0.6-3.2$ & 5 & 6 & 0.9 & $0.2-3.2$ & 1.2 & $0.6-2.5$ \\
\hline $260-268$ & Other non-metallic mineral products & 13 & 13 & 0.9 & $0.4-2.1$ & 6 & 9 & 0.8 & $0.2-2.3$ & 0.9 & $0.5-1.7$ \\
\hline $270-287$ & Basic metals and fabricated metal products & 35 & 37 & 0.8 & $0.5-1.4$ & 22 & 9 & $3.3 \ddagger$ & $1.4-7.9$ & 1.2 & $0.8-1.8$ \\
\hline $290-297$ & Machinery and equipment NEC & 45 & 50 & 0.9 & $0.6-1.4$ & 33 & 34 & 0.9 & $0.5-1.6$ & 0.9 & $0.7-1.3$ \\
\hline $300-335$ & Electrical and optical equipment & 26 & 31 & 0.8 & $0.5-1.4$ & 16 & 21 & 0.9 & $0.4-1.7$ & 0.8 & $0.5-1.3$ \\
\hline $340-355$ & Transport equipment & 22 & 30 & 0.7 & $0.4-1.2$ & 16 & 11 & 1.5 & $0.7-3.4$ & 0.9 & $0.6-1.4$ \\
\hline $360-372$ & Manufacturing NEC & 23 & 20 & 1.0 & $0.5-1.9$ & 5 & 14 & 0.4 & $0.1-1.1$ & 0.8 & $0.5-1.3$ \\
\hline $400-410$ & Electricity, gas, water supply & 10 & 6 & 1.7 & $0.6-4.8$ & 6 & 7 & 0.8 & $0.3-2.5$ & 1.2 & $0.6-2.6$ \\
\hline $450-455$ & Construction & 63 & 53 & 1.1 & $0.7-1.6$ & 52 & 40 & 1.3 & $0.8-2.1$ & 1.2 & $0.8-1.6$ \\
\hline $500-527$ & Wholesale retail trade, repair of motor vehicles etc & 108 & 108 & 1.1 & $0.8-1.5$ & 101 & 82 & 1.2 & $0.9-1.7$ & 1.1 & $0.9-1.5$ \\
\hline $550-555$ & Hotels, restaurants & 49 & 23 & $1.9 \dagger$ & $1.1-3.2$ & 15 & 21 & 0.7 & $0.4-1.5$ & 1.4 & $0.9-2.1$ \\
\hline $600-642$ & Transport, storage, communication & 32 & 36 & 0.9 & $0.5-1.4$ & 39 & 41 & 0.9 & $0.6-1.5$ & 0.9 & $0.6-1.3$ \\
\hline $650-672$ & Financial intermediation & 17 & 27 & 0.7 & $0.4-1.3$ & 26 & 30 & 0.9 & $0.5-1.5$ & 0.8 & $0.5-1.2$ \\
\hline $700-748$ & Real estate, renting, business activities & 53 & 66 & 0.8 & $0.5-1.2$ & 30 & 51 & $0.6+$ & $0.4-1.0$ & $0.7 \dagger$ & $0.5-1.0$ \\
\hline $750-753$ & $\begin{array}{l}\text { Public administration defence, compulsory social } \\
\text { security }\end{array}$ & 125 & 141 & 0.8 & $0.6-1.2$ & 42 & 48 & 0.8 & $0.5-1.3$ & 0.8 & $0.6-1.1$ \\
\hline 800-804 & Education & 191 & 191 & 1.0 & $0.8-1.3$ & 31 & 44 & 0.7 & $0.4-1.2$ & 1.0 & $0.7-1.2$ \\
\hline $850-853$ & Health, social work & 49 & 50 & 1.0 & $0.6-1.5$ & 36 & 33 & 1.1 & $0.7-1.9$ & 1.0 & $0.7-1.5$ \\
\hline $900-930$ & Other community, social, personal service activities & 30 & 32 & 0.9 & $0.5-1.6$ & 29 & 26 & 1.1 & $0.6-1.9$ & 1.0 & $0.7-1.5$ \\
\hline $950-950$ & Private households with employed persons & 50 & 47 & 1.1 & $0.7-1.7$ & 8 & 5 & 3.3 & $0.8-13.6$ & 1.2 & $0.8-1.9$ \\
\hline \multicolumn{12}{|c|}{$\begin{array}{l}\text { Reference group: having worked } 0 \text { years in the specific industry. } \\
{ }^{*} \text { Odds ratio (OR) adjusted for smoking (pack-years) and alcohol consumption. } \\
t p<0.05 \text {; } t p<0.01 \text {. } \\
\text { NEC, not elsewhere classified. }\end{array}$} \\
\hline
\end{tabular}

only for one or few lymphoma subgroups. Importantly, most of them are not based on small numbers. Partially, the involved sectors provide increased odds ratios for several lymphoma subgroups-for example, construction (NACE 450-455) to Hodgkin's lymphoma and CLL/SLL, "wholesale retail trade, repair of motor vehicles etc" (NACE 500-527) to CLL/SLL and marginal zone B cell lymphoma.

Tables 3 and 4 present the odds ratios for the association between occupational groups and lymphoma. In table 3, all lymphomas are combined; in table 4, statistically significant subentity specific odds ratios are presented. Increased odds ratios can be seen for the five occupational groups architects, engineers, and related technicians (ISCO 02-03), maids (ISCO 54), farmers (ISCO 60-61), glass formers, potters (ISCO 89) and bricklayers, carpenters, and other construction workers (ISCO 95). A decreased odds ratio can be seen for shoemakers and leather goods makers (ISCO 80). The separation of data into short term and long term exposures indicates that the altered risks seem not to be confined to the subgroup of long term exposed subjects. However, in a further occupational group, plumbers, welders, sheet metal and structural metal preparers and erectors (ISCO 87), an overall unaltered odds ratio masks an increased odds ratio among the short term exposed individuals.

For the mentioned occupational groups, the subentity analysis reveals risk patterns which do not substantially differ from the risks for all lymphoma combined, with one exception: the increased odds ratio for multiple myeloma among farmers $(\mathrm{OR}=9.2$; 95\% CI 2.6 to 33.1 ; table 4$)$ exceeds by far the odds ratio for all lymphomas combined $(\mathrm{OR}=2.4 ; 95 \% \mathrm{CI} 1.1$ to 5.4$)$ and is despite the small numbers highly significant for short term exposures as well as for long term exposures.
The subentity analysis reveals increased risks among some occupational groups that are not statistically associated with all lymphomas combined: rubber and plastic product makers (ISCO 90) constitute the only occupational group to be significantly associated with Hodgkin's lymphoma. For diffuse large B cell lymphoma, the odds ratio is considerably and highly significantly increased for metal processors (ISCO 72); however, numbers are small. Several occupational groups are highly significantly associated with follicular lymphoma: medical, dental, and veterinary workers (ISCO 06-07); sales workers (ISCO 41-45); machinery fitters, machine assemblers, and precision instrument makers (ISCO 84); and electrical fitters and related electrical and electronics workers (ISCO 85). The multiple myeloma risk for material handlers, dockers, and freight handlers (ISCO 97) is consistently increased over the short term and long term exposure categories; long term agriculture and animal husbandry workers (ISCO 62) show a considerably increased multiple myeloma risk.

In a latency analysis (data not shown; detailed results are available from the authors), only exposures up to 10 years before lymphoma diagnosis or (in controls) to lymphoma diagnosis of the matched case were included. The exclusion of recent occupational exposures did not substantially change the results for all lymphomas combined. The latency analysis of lymphoma subentities led to few changes in the results: having worked in the industrial sector basic metals and fabricated metal products was no longer significantly associated with Hodgkin's lymphoma. In the latency analysis, electrical fitters lost their significant association with diffuse large B cell lymphoma, but were significantly associated with chronic lymphocytic leukaemia. Having worked more than 10 years as a transport equipment operator was significantly 


\begin{tabular}{|c|c|c|c|c|c|c|c|c|c|c|c|}
\hline \multirow[b]{2}{*}{ NACE Rev 1} & \multirow[b]{2}{*}{ Industry } & \multicolumn{4}{|c|}{$1-10$ years } & \multicolumn{4}{|c|}{$>10$ years } & \multicolumn{2}{|l|}{ All } \\
\hline & & Cases & Controls & $\begin{array}{l}\text { Adj } \\
\text { OR† }\end{array}$ & $95 \% \mathrm{Cl} C$ & Cases & s Controls & $\begin{array}{l}\text { Adj } \\
\text { ORt }\end{array}$ & $95 \% \mathrm{Cl}$ & $\begin{array}{l}\text { Adi } \\
\text { ORt }\end{array}$ & $95 \% \mathrm{Cl}$ \\
\hline \multicolumn{12}{|c|}{ Hodgkin's lymphoma $(n=116)$} \\
\hline $270-287$ & $\begin{array}{l}\text { Basic metals and fabricated metal } \\
\text { products }\end{array}$ & 9 & 37 & 2.1 & $0.9-5.0$ & 3 & 9 & $4.3+$ & $1.0-18.4$ & $2.4 \dagger$ & $1.1-5.3$ \\
\hline $450-455$ & Construction & 14 & 53 & $2.3+$ & $1.1-4.8$ & 8 & 40 & 1.7 & $0.7-4.3$ & $2.0+$ & $1.1-3.8$ \\
\hline \multicolumn{12}{|c|}{ B cell non-Hodgkin's lymphoma (total) $(n=554)$} \\
\hline \multicolumn{12}{|c|}{ Diffuse large B cell lymphoma $(n=158)$} \\
\hline $270-287$ & $\begin{array}{l}\text { Basic metals and fabricated metal } \\
\text { products }\end{array}$ & 8 & 37 & 1.0 & $0.5-2.3$ & 6 & 9 & $4.3 \ddagger$ & $1.4-12.8$ & 1.5 & $0.8-3.0$ \\
\hline $550-555$ & Hotels, restaurants & 11 & 23 & $2.2 \dagger$ & $1.0-4.6 \quad 1$ & 10 & 21 & $2.2 \dagger$ & $1.0-5.0$ & $2.2 \dagger$ & $1.3-3.9$ \\
\hline \multicolumn{12}{|c|}{ Follicular lymphoma (n=92) } \\
\hline $150-160$ & Food products, beverages, tobacco & 9 & 30 & $2.4 \dagger$ & $1.1-5.4$ & 5 & 15 & $3.3+$ & $1.1-9.7$ & $2.7 \ddagger$ & $1.4-5.2$ \\
\hline $190-193$ & Leather, leather products & 4 & 18 & 1.5 & $0.5-4.9$ & 3 & 2 & $13.9 \neq$ & $2.2-89.7$ & $2.6+$ & $1.0-6.7$ \\
\hline $340-355$ & Transport equipment & 2 & 30 & 0.5 & $0.1-2.4$ & 4 & 11 & $3.5+$ & $1.0-11.6$ & 1.3 & $0.5-3.2$ \\
\hline $850-853$ & Health, social work & 8 & 50 & 1.2 & $0.5-2.81$ & 13 & 33 & $3.4 \ddagger$ & $1.7-7.1$ & $2.1 \dagger$ & $1.2-3.6$ \\
\hline \multicolumn{12}{|c|}{$\begin{array}{l}\text { Chronic lymphocytic leukaemia (CLL)/small lymphocytic } \\
\text { lymphoma (SLL) }(n=104)\end{array}$} \\
\hline $150-160$ & Food products, beverages, tobacco & 7 & 30 & 1.8 & $0.7-4.3 \quad 1$ & 11 & 15 & $5.0 \ddagger$ & $2.2-11.6$ & $3.0 \ddagger$ & $1.6-5.5$ \\
\hline $450-455$ & Construction & 13 & 53 & 1.5 & $0.7-3.0 \quad 1$ & 15 & 40 & $2.1 \dagger$ & $1.1-4.1$ & $1.8 \dagger$ & $1.0-3.0$ \\
\hline $500-527$ & $\begin{array}{l}\text { Wholesale retail trade, repair of } \\
\text { motor vehicles etc }\end{array}$ & 14 & 108 & 1.3 & $0.7-2.4 \quad 2$ & 21 & 82 & $1.9+$ & $1.1-3.4$ & $1.6+$ & $1.0-2.5$ \\
\hline \multicolumn{12}{|c|}{ Plasma cell myeloma (plasmacytoma) $(n=76)$} \\
\hline $010-020$ & Agriculture, hunting, forestry & 7 & 63 & 1.0 & $0.4-2.3$ & 8 & 18 & $4.1 \ddagger$ & $1.7-10.5$ & 1.7 & $0.9-3.2$ \\
\hline $210-223$ & $\begin{array}{l}\text { Pulp paper, paper products, } \\
\text { publishing and printing }\end{array}$ & 5 & 14 & $3.5+$ & $1.1-11.5$ & 4 & 12 & $3.3^{+}$ & $1.0-10.8$ & $3.4 \ddagger$ & $1.4-8.0$ \\
\hline $750-753$ & $\begin{array}{l}\text { Public administration, defence, } \\
\text { compulsory social security }\end{array}$ & 5 & 141 & $0.2 \ddagger$ & $0.1-0.6$ & 6 & 48 & 0.9 & $0.4-2.3$ & $0.4 \dagger$ & $0.2-0.8$ \\
\hline \multicolumn{12}{|c|}{ Marginal zone B cell lymphoma $(n=38)$} \\
\hline $500-527$ & $\begin{array}{l}\text { Wholesale retail trade, repair of } \\
\text { motor vehicles etc }\end{array}$ & 12 & 108 & $3.2 \ddagger$ & $1.4-7.1$ & 9 & 82 & $2.8+$ & $1.2-6.6$ & $3.0 \ddagger$ & $1.5-5.9$ \\
\hline $750-753$ & $\begin{array}{l}\text { Public administration defence, } \\
\text { compulsory social security }\end{array}$ & 7 & 141 & 1.4 & $0.5-3.6$ & 7 & 48 & $3.6+$ & $1.4-9.4$ & 2.0 & $0.9-4.4$ \\
\hline \multicolumn{12}{|c|}{ T cell and NK cell non-Hodgkin's lymphoma $(n=35)$} \\
\hline $210-223$ & $\begin{array}{l}\text { Pulp paper, paper products, } \\
\text { publishing and printing }\end{array}$ & 4 & 14 & $8.8 \ddagger$ & $2.5-30.7$ & 1 & 12 & 2.2 & $0.3-18.2$ & $5.5 \ddagger$ & $1.9-16.0$ \\
\hline
\end{tabular}

associated with follicular lymphoma (ISCO 98). According to the latency analysis, sales workers (ISCO 41-45) showed-in addition to the increased follicular lymphoma risk-a significantly increased CLL and marginal zone B cell lymphoma risk. Having worked more than 10 years as an agriculture and animal husbandry worker (ISCO 62) was associated with diffuse large B cell lymphoma. Finally, cabinet makers (ISCO 51) had a significantly increased CLL risk ( $<10$ years exposure) and plasmacytoma risk in the latency analysis.

\section{DISCUSSION}

In this study, several economical/industrial sectors and occupational groups show an increased and some a decreased lymphoma risk. Due to the broad definition of the respective categories, these findings are not directly conclusive for a causal relation. However, they provide indications to potentially hazardous exposures which may be worth considering in more detail in subsequent analyses. These include solvents, electromagnetic fields, mineral dusts, pesticides, viruses, and others.

\section{Solvents}

Exposure to solvents can occur in the economical/industrial sectors (a) pulp paper, paper products, publishing and printing, (b) chemicals, chemical products, and man-made fibres, (c) basic metals and fabricated metal products, and in the occupational groups (d) shoemakers and leather goods makers, (e) printers, (f) rubber and plastic product makers, and to some extent among ( $\mathrm{g}$ ) bricklayers, carpenters, and other construction workers, (h) maids on the level of household application, (i) plumbers, welders, sheet metal and structural metal preparers, and erectors, (j) metal processors, (k) machinery fitters, and (l) cabinet makers. For the mentioned industries and occupations, increased odds ratios were observed with the exception of (b); shoemakers and leather goods makers (d) are significantly negatively associated with all lymphomas combined, but (non-significantly) positively associated with follicular lymphoma. Increased risks among cabinet makers (1) were found solely in the latency analysis. The mentioned increased risks are concordant with several previous studies which pointed to a potential relation between solvent exposure and lymphoma. ${ }^{36-43}$ Due to small sample sizes, we could not conclusively determine whether the found increased risks are 
Table 3 Odds ratios and $95 \%$ confidence limits for occupational groups in relation to lymphomas ( $\mathrm{n}=710$ matched pairs; only sectors with at least five cases are presented)

\begin{tabular}{|c|c|c|c|c|c|c|c|c|c|c|c|}
\hline \multirow[b]{2}{*}{$\begin{array}{l}\text { ISCO- } \\
68\end{array}$} & \multirow[b]{2}{*}{ Occupational group } & \multicolumn{4}{|c|}{$1-10$ years } & \multicolumn{4}{|c|}{$>10$ years } & \multicolumn{2}{|l|}{ All } \\
\hline & & Cases & Controls & Adj $O R^{*}$ & $95 \% \mathrm{Cl}$ & Cases & Controls & $\begin{array}{l}\text { Adj } \\
\text { OR }^{*}\end{array}$ & $95 \% \mathrm{Cl}$ & Adj $O R^{*}$ & $95 \% \mathrm{Cl}$ \\
\hline $01 ; 05$ & Physical scientists; life scientists & 7 & 7 & 1.3 & $0.4-3.9$ & 7 & 10 & 0.8 & $0.3-2.3$ & 1.0 & $0.5-2.2$ \\
\hline $02-03$ & $\begin{array}{l}\text { Architects, engineers, and related } \\
\text { technicians }\end{array}$ & 21 & 16 & 2.0 & $1.0-4.2$ & 34 & 32 & 1.5 & $0.9-2.7$ & $1.7 \dagger$ & $1.0-2.7$ \\
\hline $06-07$ & $\begin{array}{l}\text { Medical, dental, veterinary, and related } \\
\text { workers }\end{array}$ & 21 & 27 & 0.9 & $0.5-1.6$ & 17 & 18 & 1.3 & $0.6-2.6$ & 1.0 & $0.6-1.7$ \\
\hline $\begin{array}{l}11 ; 14 ; \\
17-18\end{array}$ & ; Other professional and technical workers & 5 & 6 & 1.0 & $0.3-3.3$ & 8 & 4 & 2.3 & $0.7-7.9$ & 1.5 & $0.6-3.6$ \\
\hline 13 & Teachers & 15 & 26 & 0.7 & $0.3-1.4$ & 18 & 27 & 0.9 & $0.5-1.8$ & 0.8 & $0.5-1.3$ \\
\hline $\begin{array}{l}31 ; \\
35-38\end{array}$ & Other clerical workers & 25 & 15 & $2.2 \dagger$ & $1.1-4.7$ & 21 & 27 & 1.0 & $0.5-2.0$ & 1.5 & $0.9-2.4$ \\
\hline $41-45$ & Sales workers & 58 & 55 & 1.3 & $0.8-2.0$ & 74 & 70 & 1.2 & $0.8-1.9$ & 1.3 & $0.9-1.8$ \\
\hline 51 & $\begin{array}{l}\text { Working proprietors (catering and } \\
\text { lodging services) }\end{array}$ & 8 & 2 & 3.7 & $0.8-17.7$ & 1 & 2 & 0.6 & $0.1-7.2$ & 2.3 & $0.7-7.5$ \\
\hline 53 & Cooks, waiters, bartenders & 15 & 13 & 1.4 & $0.6-3.1$ & 12 & 13 & 1.2 & $0.5-2.7$ & 1.3 & $0.7-2.4$ \\
\hline 54 & Maids & 78 & 61 & $1.6+$ & $1.1-2.9$ & 15 & 8 & $2.8 \dagger$ & $1.1-7.0$ & $1.7 \ddagger$ & $1.2-2.6$ \\
\hline 55 & $\begin{array}{l}\text { Building caretakers, charworkers, } \\
\text { cleaners }\end{array}$ & 17 & 15 & 1.3 & $0.6-2.7$ & 8 & 12 & 0.7 & $0.3-1.9$ & $1.1^{+}$ & $0.6-1.9$ \\
\hline 56 & Launderers, dry cleaners, and pressers & 6 & 9 & 0.8 & $0.3-2.5$ & 5 & 2 & 3.4 & $0.6-18.5$ & 1.3 & $0.5-3.2$ \\
\hline 57 & Hairdressers, barbers, beauticians & 5 & 5 & 1.1 & $0.3-3.9$ & 3 & 7 & 0.5 & $0.1-2.0$ & 0.7 & $0.3-1.9$ \\
\hline 58 & Protective service workers & 6 & 7 & 1.2 & $0.4-3.7$ & 7 & 6 & 1.3 & $0.4-4.1$ & 1.3 & $0.6-2.8$ \\
\hline $52 ; 59$ & Other service workers & 14 & 12 & 1.4 & $0.6-3.2$ & 5 & 5 & 1.3 & $0.4-4.8$ & 1.4 & $0.7-2.8$ \\
\hline $60-61$ & Farmers & 8 & 4 & 2.8 & $0.8-9.7$ & 10 & 6 & 2.1 & $0.7-6.1$ & $2.4 \dagger$ & $1.1-5.4$ \\
\hline 62 & $\begin{array}{l}\text { Agriculture and animal husbandry } \\
\text { workers }\end{array}$ & 39 & 53 & 0.8 & $0.5-1.4$ & 18 & 12 & 1.9 & $0.9-4.1$ & 1.0 & $0.7-1.6$ \\
\hline 70 & $\begin{array}{l}\text { Production supervisors and general } \\
\text { foremen }\end{array}$ & 9 & 9 & 1.3 & $0.5-3.4$ & 10 & 17 & 0.7 & $0.3-1.6$ & 0.9 & $0.5-1.7$ \\
\hline 72 & Metal processors & 6 & 5 & 1.4 & $0.4-5.1$ & 4 & 1 & 5.2 & $0.6-48.8$ & 2.1 & $0.7-6.3$ \\
\hline 74 & Chemical processors and related workers & 12 & 11 & 1.1 & $0.5-2.7$ & 9 & 3 & 3.4 & $0.9-13.0$ & 1.6 & $0.8-3.3$ \\
\hline 75 & Spinners, weavers, knitters, dyers & 10 & 10 & 1.3 & $0.5-3.3$ & 1 & 5 & 0.3 & $0.03-2.5$ & 1.0 & $0.4-2.2$ \\
\hline 77 & Food and beverage processors & 16 & 14 & 1.4 & $0.6-3.0$ & 11 & 5 & 2.8 & $0.9-8.5$ & 1.7 & $0.9-3.3$ \\
\hline 79 & Tailors, dressmakers, sewers, upholsterers & 25 & 26 & 1.2 & $0.6-2.3$ & 15 & 14 & 1.3 & $0.6-2.8$ & 1.3 & $0.7-2.2$ \\
\hline 80 & Shoemakers and leather goods makers & 5 & 14 & 0.4 & $0.1-1.1$ & 1 & 4 & 0.3 & $0.04-3.0$ & $0.4 \dagger$ & $0.1-1.0$ \\
\hline 81 & Cabinet makers & 17 & 10 & 1.7 & $0.7-4.0$ & 8 & 15 & 0.6 & $0.3-1.5$ & 1.1 & $0.6-1.9$ \\
\hline 83 & $\begin{array}{l}\text { Blacksmiths, toolmakers, and machine } \\
\text { tool operators }\end{array}$ & 21 & 32 & 0.8 & $0.4-1.4$ & 14 & 14 & 1.2 & $0.5-2.5$ & 0.9 & $0.5-1.5$ \\
\hline 84 & $\begin{array}{l}\text { Machinery fitters, machine assemblers, } \\
\text { and precision instrument makers (except } \\
\text { electrical) }\end{array}$ & 48 & 49 & 1.1 & $0.7-1.8$ & 38 & 32 & 1.4 & $0.8-2.4$ & 1.2 & $0.8-1.8$ \\
\hline 85 & $\begin{array}{l}\text { Electrical fitters and related electrical } \\
\text { and electronics workers }\end{array}$ & 24 & 31 & 0.9 & $0.5-1.6$ & 19 & 10 & 2.2 & $1.0-5.1$ & 1.2 & $0.7-2.0$ \\
\hline 87 & $\begin{array}{l}\text { Plumbers, welders, sheet metal and } \\
\text { structural metal preparers, and erectors }\end{array}$ & 31 & 19 & $1.9 \dagger$ & $1.0-3.5$ & 8 & 20 & 0.5 & $0.2-1.2$ & 1.2 & $0.7-2.1$ \\
\hline 89 & Glass formers, potters & 4 & 1 & 5.4 & $0.6-49.4$ & 4 & 1 & 6.4 & $0.7-58.8$ & $5.9+$ & $1.2-28.4$ \\
\hline 90 & Rubber and plastics product makers & 11 & 9 & 1.7 & $0.7-4.4$ & 2 & 2 & 1.4 & $0.2-10.6$ & 1.7 & $0.7-3.9$ \\
\hline 92 & Printers & 7 & 11 & 0.9 & $0.3-2.4$ & 11 & 6 & 2.4 & $0.9-6.8$ & 1.4 & $0.7-2.9$ \\
\hline 93 & Painters & 4 & 5 & 0.9 & $0.2-3.6$ & 6 & 5 & 1.1 & $0.3-3.9$ & 1.0 & $0.4-2.6$ \\
\hline 94 & Production and related workers & 7 & 6 & 1.2 & $0.4-3.6$ & - & 3 & - & - & 0.9 & $0.3-2.7$ \\
\hline 95 & $\begin{array}{l}\text { Bricklayers, carpenters, and other } \\
\text { construction workers }\end{array}$ & 32 & 30 & 1.3 & $0.7-2.4$ & 25 & 10 & $2.9 \dagger$ & $1.3-6.9$ & $1.7 \dagger$ & $1.0-2.8$ \\
\hline 97 & $\begin{array}{l}\text { Material handling and related equipment } \\
\text { operators, dockers, and freight handlers }\end{array}$ & 25 & 20 & 1.3 & $0.7-2.5$ & 12 & 6 & 2.0 & $0.7-5.6$ & 1.5 & $0.9-2.6$ \\
\hline & Transport equipment operators & 27 & 25 & 1.3 & $0.7-2.3$ & 29 & 25 & 1.4 & $0.7-2.6$ & 1.3 & $0.8-2.1$ \\
\hline $\begin{array}{l}76 ; 78 ; \\
86 ; 91 ; \\
96 ; 99\end{array}$ & ; Other production workers and labourers & 32 & 24 & 1.4 & $0.8-2.6$ & 14 & 12 & 1.3 & $0.6-2.9$ & 1.4 & $0.8-2.3$ \\
\hline
\end{tabular}

Reference group: 0 years and non-exposed white collar works as main occupation: ISCO-68 groups 08, 09, 12, 15, 19, 20-21, 30, 32-34, 39, 40, 50 (statisticians, mathematicians, system analysts, economists, jurists, authors, journalists, other professional or technical workers; legislative officials and government administrators, managers, clerical supervisors; stenographers, typists, and card and tape punching machine operators, bookkeepers, cashiers, computing machine operators, other clerical related workers).

*Odds ratio (OR) adjusted for smoking (pack-years) and alcohol consumption; probands with blue collar work as main occupation were analysed in a separate category (not shown).

$\mathrm{tp}<0.05 ; \neq \mathrm{p}<0.01$.

confined to specific target subentities. Some particularly strongly increased odds ratios indicate that such specific targets might exist (for example, multiple myeloma in the pulp paper, paper products, publishing and printing sector), but they might not necessarily be caused by solvents. Furthermore, in our study several occupations which can be expected to be prone to solvent exposure (for example, dry cleaners, painters) are not associated with lymphoma diagnosis. Larger study sizes to overcome the limitation of too small sample sizes for a proper subentity analysis and the application of job exposure matrices (JEM) to focus on exposure to specific agents are the next steps required to prosecute these indications.

The decreased odds ratio just for the industrial sector chemicals, chemical products, and man-made fibres (b) points to a fundamental problem of analysing occupational cancer studies along industrial sectors: the grouping of employees by such sectors may lead to conglomerates of 


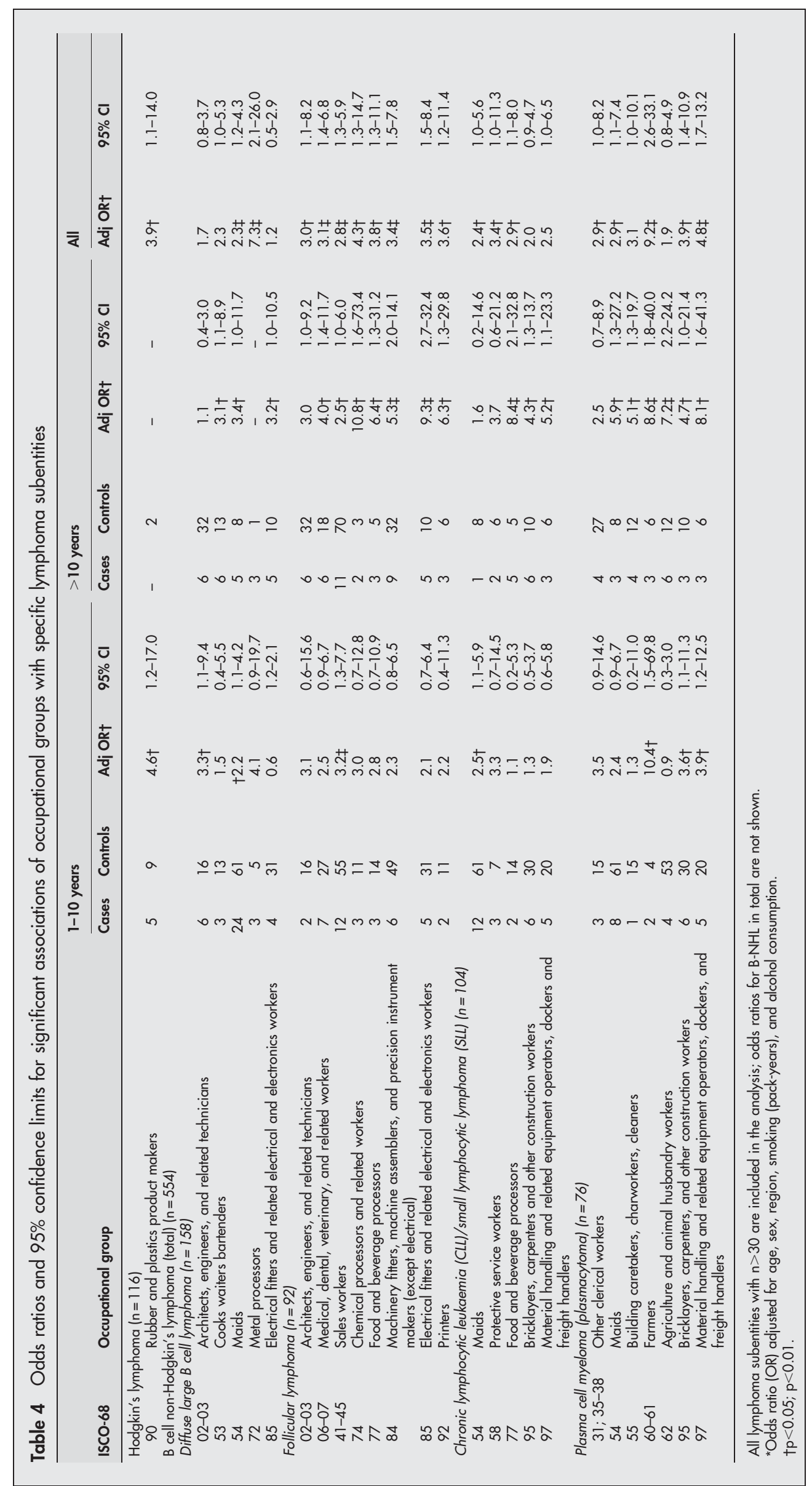


rather different workplaces and factual exposures with unpredictable overall risks. When employees in the chemical sector with non-exposed white collar work as main occupation (nine cases, 17 control subjects) were excluded from the analysis, the negative association between working in the chemical sector and lymphoma diagnosis lost its statistical significance.

In accordance with Persson et al, ${ }^{17}$ our data suggest an association between rubber and plastics work and Hodgkin's lymphoma, but not NHL (except marginal zone B cell lymphoma). In a later publication, the mentioned study group also revealed an increased NHL risk for workers exposed to plastic and rubber chemicals. ${ }^{44}$ Rubber and plastics workers might be occupationally exposed to solvents (particularly benzene), aromatic amines, nitrosamines, and polycyclic aromatic hydrocarbons. In 1982 an International Agency for Research on Cancer (IARC) working group ${ }^{45}$ concluded that there was sufficient evidence for excess mortality from leukaemia among workers employed in the rubber industry. A recently published cohort study ${ }^{46}$ revealed an increased mortality from leukaemia, but not from NHL among rubber hydrochloride workers. Similarly, in a large German cohort study, mortality from leukaemia (ICD-9 204208), but not from lymphoma (ICD-9 200-203) was significantly increased among rubber workers in the areas "preparation of materials" and "technical rubber goods" ${ }^{47}$ In our study, chronic lymphocytic leukaemia risk was not significantly increased among rubber workers; however, numbers were small. Although there is nevertheless sufficient evidence for an association between rubber work and leukaemia, the evidence to date for an association between rubber work and lymphoma is weak. However, one has to point out that according to the ICD classification some NHL (lymphatic leukaemia) are classified as leukaemia, not as lymphoma. Therefore most epidemiological studies on leukaemia have included some NHL cases in their case definition.

\section{Electromagnetic fields}

In our study, the occupational groups plumbers and welders as well as electrical workers showed an increased odds ratio. As a potentially underlying commonality, the exposure to electromagnetic fields has to be taken into account, though the so far available literature appears inconsistent. For orientation, we took a first look on exposure assessment by a Finnish job exposure matrix (FINJEM) ${ }^{48}$ and found that only follicular lymphoma were significantly positively associated with magnetic field exposure. Several studies point to a potential relation between electromagnetic fields and NHL; ${ }^{26}{ }^{42}{ }^{49-55}$ other studies fail to demonstrate an excess risk in NHL among people exposed to electromagnetic fields. ${ }^{28}$ 56-59 Though several potential modes of action of electromagnetic fields on calcium ion homeostasis, ${ }^{60}$ protein kinases, ${ }^{61}$ ornithine decarboxylase, ${ }^{62}$ and immune response of cells ${ }^{63}$ have been proposed, convincing mechanistic pathways from electromagnetic fields to lymphoma are still lacking.

\section{Mineral dusts}

The two mentioned occupational groups (plumbers and welders as well as electrical workers), together with chemical processors and construction workers, might also have been exposed to mineral dusts including asbestos. Several epidemiological studies point to a potential aetiological relevance of asbestos exposure to lymphoma; ${ }^{64-66}$ (for an overview see Becker et $\mathrm{al}^{67}$ ) other studies do not support this relation..$^{23} 26$ 68-71 Dodson et $a l^{72}$ detected asbestos fibres in the thoracic lymph nodes of exposed subjects. Therefore, lymph nodes as part of the drainage system of the gastrointestinal organs might get directly in contact with asbestos fibres. As an alternative pathophysiological explanation, lymph nodes might be indirectly involved in the inflammatory process related to the interaction between the fibres inhaled or ingested and the respective tissues. ${ }^{67}{ }^{73}$ When the exposure to asbestos was assessed by the FINJEM, low asbestos exposure was found to be significantly associated with B cell NHL in total, follicular lymphoma, and marginal cell lymphoma. In accordance with these results, Blair et al revealed a significant association between asbestos exposure and follicular lymphoma. ${ }^{27}$

\section{Pesticides}

The increased odds ratio of farmers and agriculture workers points to several potentially carcinogenic exposures including pesticides. Additionally, extensive insecticide use in the household may even be a cofactor of the increased odds ratio among maids. Many previous studies indicated an increased lymphoma risk-especially an increased multiple myeloma risk-by pesticide exposure. ${ }^{74-83}$ The carcinogenic effects of pesticides may be associated with their genotoxicity and immunotoxicity, ${ }^{84-86}$ increased cell proliferation, ${ }^{87}$ and association with chromosomal aberrations. ${ }^{88}$ Again, in our study the definition of agricultural workers is too crude to draw definite conclusions about an aetiological role of pesticides: Pesticides constitute a heterogeneous group of chemical substances; not all agricultural workers apply pesticides; even among those who do, exposure frequency varies considerably. Nevertheless, some studies point to a specific aetiological role of pesticides at least for multiple myeloma: although Demers et al found only a small excess risk among all agricultural workers combined, ${ }^{81}$ the risk of multiple myeloma was strongly increased among agricultural workers who reported having been highly exposed to pesticides. Furthermore, a recently published study reveals an increased mortality from multiple myeloma among phenoxy herbicide producers and sprayers. ${ }^{89}$ Precise exposure assessment and application of JEM should help to address the relation between specific pesticides and specific lymphoma subentities more conclusively. According to a preliminary FINJEM analysis, B cell NHL in total, follicular lymphoma, and multiple myeloma, but not Hodgkin's lymphoma, are significantly associated with pesticides.

\section{Viruses and others}

A further potential exposure of farmers, agriculture, and husbandry workers is that to cattle and thus to zoonotic infectious agents. According with this hypothesis, the case control study of Nanni et al reveals associations between NHL as well as CLL with farming and animal breeding, but not with farming alone. ${ }^{75}$ The exposure to zoonotic infectious agents must also be taken into account when considering the increased odds ratio in the industrial sector food products which comprises processing of meat and meat products, and potentially even regarding the increased risk of maids who may have close contact with pet excrement while cleaning the cages. Additionally, our study ${ }^{33}$ as well as several other studies $^{90-93}$ revealed a significant association between contact to cattle and lymphoma risk. Not only zoonotic, but also human to human transmission of infectious agents might play a potential aetiological role for lymphoma. In our study, the increased lymphoma risks of maids, sales workers, and medical personnel might be related to human-to-human transmission of infectious agents. However, other occupations with frequent public contact (for example, teachers) are not associated with lymphoma diagnosis in our study.

Our finding of an increased lymphoma risk among architects, engineers, and other technicians has not been previously reported. However, these occupations may be involved in working processes of the construction or 
industrial production area and could be subsumed under the respective exposures.

\section{Latency period analyis}

The average latency time from start of occupational exposure until the diagnosis of acute leukaemia might be about $10-11$ years. ${ }^{94}$ It is not clear if this latency period is valid also for lymphomas. To exclude potentially "non-causal" occupational exposures from analysis, in an additional analysis we considered only exposures up to 10 years before the lymphoma diagnosis. On the whole, the exclusion of recent occupational exposures led to slightly increasing lymphoma risks. The results of the latency analysis are to a large extent compatible with a potential role of solvents, electromagnetic fields, mineral dusts, pesticides, and viruses in the aetiology of lymphomas.

\section{Limitations}

Exposure assessment based on job and industry titles always implies misclassification of exposure to known and unknown carcinogens. Several potentially hazardous substances (for example, solvents) are used in many different occupations and industries; therefore, the risk estimates might be diluted when each occupation or industry category is examined separately. Moreover, subjects included in the reference group might have actually had exposures from other occupational or industrial categories similar to the subjects in an exposed group. Due to small numbers, particularly for rare lymphoma subentities, the power of the study to detect risk factors is limited. On the other hand, several tests were performed, introducing a problem of multiple comparisons.

Furthermore, the low response rate among control subjects might have introduced selection bias. However, when only the two study regions with the highest response rate (Heidelberg and Bielefeld: response rate, 50\%) are included in the analysis, the results do not substantially change. Moreover, it is worth mentioning that we used a conservative approach to calculate participation rates. If we had excluded individuals from the denominator-as done in some studies-who could not be reached or did not participate due to illnesses, the participation increased to $56 \%$ for men and $50 \%$ for women. The main difference of calculation is related to failure of getting contact to the randomly selected control subjects (for example, no reply to several mail contact attempts and no telephone number identifiable) who are counted as non-participants in our study, but left out of consideration in many other studies.

\section{CONCLUSIONS}

To further clarify the association between specific occupational exposures and cancer subentities, there is a need for multinational epidemiological studies applying a common study protocol and questionnaire. For this purpose, our study will be evaluated as a multinational epidemiological case control study of lymphoma (EPILYMPH) in eight countries, coordinated by the International Agency for Research on Cancer.

\section{ACKNOWLEDGEMENTS}

We are indebted to the participants of the study and to the many colleagues who supported the performance of the study. Detailed lists are presented in former publications. ${ }^{33}{ }^{34}$

\section{Authors' affiliations}

B Mester, G Elsner, A Seidler, Institute of Occupational Medicine, Johann Wolfgang Goethe-University, Frankfurt/Main, Germany

A Nieters, E Deeg, N Becker, German Cancer Research Center (DKFZ), Division of Clinical Epidemiology, Heidelberg, Germany

\section{Main messages}

- In a population based case control study applying the new WHO classification, occupations with potential exposure to pesticides, solvents, electromagnetic fields, mineral dusts, and viruses were found to be associated with lymphoma risk.

- According to our study, risk factors might differ between specific lymphoma subentities. A particularly strong association was found between multiple myeloma and agriculture work including farming and animal husbandry.

\section{Policy implications}

- To further clarify the association between specific occupational exposures and cancer subentities, there is a need for multinational epidemiological studies applying a common study protocol and questionnaire. For this purpose, our study will be evaluated as a multinational epidemiological case control study of lymphoma (EPILYMPH) in eight countries, coordinated by the International Agency for Research on Cancer (IARC).

The study was funded by the Federal Office for Radiation Protection (StSch4261 and StSch4420). The European Community supported the set up of a common protocol for assessment of occupational exposures (SOC 98201307 05F02) and implementation of additional study areas (QLK4-CT-2000-00422). A recent workshop of the industrial hygienists in Heidelberg was funded by the German Research Foundation (4850/ 161/03).

The authors declare that they do not have any competing interests.

The study protocol has been approved by the ethics committees of Ruprecht-Karls University Heidelberg, Landesärztekammer RheinlandPfalz, Würzburg University, Ärztekammer Hamburg, and Bielefeld University.

\section{REFERENCES}

1 Baris D, Zahm SH. Epidemiology of lymphomas. Curr Opin Oncol 2000; 12:383-94.

2 Devesa SS, Fears T. Non-Hodgkin's lymphoma time trends: United States and international data. Cancer Res 1992;52(Suppl):5432s-40s.

3 Hartge P, Devesa SS. Quantification of the impact of known factors on time trends in Non-Hodgkin's lymphoma incidence. Cancer Res 1992;52(suppl):5566-9.

4 Holford TR, Zheng T, Mayne ST, et al. Time trends of non-Hodgkin's lymphoma: are they real? What do they mean? Cancer Res 1992;52(suppl):5443s-5446s.

5 Arbeitsgemeinschaft Bevölkerungsbezogener Krebsregister in Deutschland. Krebs in Deutschland. 4th ed. Saarbrücken 2004.

6 Bernstein L, Ross RK. Prior medication use and health history as risk for non-Hodgkin's lymphoma: preliminary results from a case-control study in Los Angeles County. Cancer Res 1992;52(Suppl):5510-15

7 Filipovich $\mathrm{AH}$, Mathur A, Kamat D, et al. Primary immundeficiencies: genetic risk factors for lymphoma. Cancer Res 1992;52(suppl):5465-546

8 Kinlen L. Immunosuppressive therapy and acquired immunological disorders. Cancer Res 1992;52(suppl):5474-6.

9 Fabbro-Peray P, Daures J-P, Rossi J-F. Environmental risk factors for NonHodgkin's lymphoma: a population-based case-control study in LanguedocRoussillon, France. Cancer Causes Control 2001;12:201-12.

10 Armenian HK, Hoover DR, Rubb S, et al. Risk factors for non-Hodgkin's lymphoma in acquired immunodeficiency syndrome (AIDS). Am J Epidemiol 1996; 143:374-9.

11 Birkeland SA, Storm HH, Lamm LU, et al. Cancer risk after renal transplantation in the Nordic Countries, 1964-1986. Int J Cancer 1995;60:183-9. 
12 Rowlings PA, Curtis RE, Passweg JR, et al. Increased incidence of Hodgkin's disease after allogenic bone marrow transplantation. J Clin Oncol 1999;17:3122-7.

13 Grulich AE. AIDS-associated Non-Hodgkin's lymphoma in the era of highly active antiretroviral therapy. J Aquir Immune Defic Syndr 1999;21:S31-3.

14 Petruckevitch A, Del Amo J, Philips AN, et al. Risk of cancer in patients with HIV disease. Int J STD AIDS 1999; 10:38-42.

15 Brownson RC, Reif JS. A cancer registry-based study of occupational risk for lymphoma, multiple myeloma and leukaemia. Int J Epidemiol 1988;17:27-32.

16 LaVecchia C, Negri E, D'Avanzo B, et al. Occupation and lymphoid nonHodgkin lymphoma. Br J Cancer 1989;60:385-8.

17 Persson B, Dahlander AM, Fredriksson M, et al. Malignant lymphomas and occupational exposures. Br J Ind Med 1989:46:516-20.

18 McCunney RJ. Hodgkin's disease, work, and the environment. J Occup Environ Med 1999;41:36-46.

19 Briggs NC, Levine RS, Hall HI, et al. Occupational risk factors for selected cancers among African American and white men in the United States. Am J Public Health 2003;93:1748-52.

20 Persson B, Fredriksson M, Olsen K, et al. Some occupational exposures for malignant lymphomas. Cancer 1993;72:1773-8

21 Seniori Costantini A, Miligi L, Kriebel D, et al. A multicenter case-control study in Italy on hematolymphopoietic non-Hodgkin lymphoma and occupation. Epidemiology 2001;12:78-87.

22 Grufferman S, Delzell E. Epidemiology of Hodgkin's disease. Epidemiol Rev 1984:76-106.

23 Schumacher MC, Delzell E. A death-certificate case-control study of nonHodgkin's lymphoma and occupation in men in North Carolina. Am J Ind Med 1988;13:317-30

24 Kelleher C, Newell J, MacDonagh-White C, et al. Incidence and occupational pattern of leukaemias, lymphomas, and testicular tumours in western Ireland over an 11 years period. J Epidemiol Community Health 1998:52:651-6.

25 Skov T, Lynge E. Non-Hodgkin's lymphoma and occupation in Denmark. Scand J Soc Med 1991;19:162-9.

26 Linet MS, Malker HS, McLaughlin JK, et al. Non-Hodgkin's lymphoma and occupation in Sweden: a registry based analysis. Br J Ind Med 1993;50:79-84.

27 Blair A, Linos A, Stewart PA, et al. Evaluation of risks for non-Hodgkin's lymphoma by occupation and industry exposures from a case-control study. Am J Ind Med 1993;23:301-12.

28 Scherr PA, Hutchison GB, Neiman S. Non-Hodgkin's lymphoma and occupational exposure. Cancer Res 1992;52(suppl):5503-9.

29 Fritschi L, Siemiatycki J. Lymphoma, myeloma and occupation: results of a case-control-study. Int J Cancer 1996;67:498-503.

30 Miligi L, Seniori Costantini AS, Crosignani P, et al. Occupational, environmental, and life-style factors associated with the risk of hematolymphopoetic malginancies in women. Am J Ind Med 1999;36:60-9.

31 Harris NL, Jaffe ES, Stein H, et al. A revised European-American classification of lymphoid neoplasms: a proposal from the International Lymphoma Study Group. Blood 1994:84:1361-92.

32 Jaffe ES, Harris NL, Stein H, et al. Pathology and genetics of tumours of haematopoietic and lymphoid tissues. International Agency for Research on Cancer. Lyon: IARC Press 2001

33 Becker N, Deeg E, Nieters A. Population-based study of lymphoma in Germany: rationale, study design and first results. Leuk Res 2004;28:713-24.

34 Becker N, Deeg E, Rüdiger T, et al. Medical history and risk for lymphoma: results of a population-based case-control study in Germany. Eur J Cancer 2005;41:133-42.

35 Bolm-Audorff U, Ahrens W, Jöckel K-H, et al. Experience with supplementary questionnaires in a lung cancer case reference study. In: Hemon $D$, Goldberg M, eds. Proceedings of the workshop on methodology of assessment of occupational exposures in the context of epidemiology detection of cancer risks. Paris, 18-19 February 1988. Luxembourg: Office for the Official Publications of the European Communities 1989:117-68.

36 Aksoy M, Erdem S, Dincol K, et al. Chronic exposure to benzene as a possible contributary etiologic factor in Hodgkin's disease. Blut 1974;28:293-8.

37 Vianna NJ, Polan A. Lymphomas and occupational benzene exposure. Lancet 1979; 1:1394-5.

38 Olsson H, Brandt L. Occupational exposure to organic solvents and Hodgkin's disease in men. Scand J Work Environ Health 1980;6:302-5

39 Raaschou-Nielsen O, Hansen J, McLaughlin JK, et al. Cancer risk among workers at Danish companies using trichloroethylene: a cohort study. Am J Epidemiol 2003;158:1182-92.

40 Rego MAV. Non-Hodgkin's lymphoma risk derived from exposure to organic solvents: a review of epidemiologic studies. Cad Saude Publica 1998; 14:41-66.

41 O'Connor SR, Farmer PB, Lauder I. Benzene and non-Hodgkin's lymphoma. J Pathol 1999; 189:448-53.

42 Dryver E, Brandt L, Kauppinen T, et al. Occupational exposures and nonHodgkin's lymphoma in Southern Sweden. Int J Occup Environ Health 2004;10:13-21.

43 Persson B, Fredriksson M. Some risk factors for non-Hodgkin's lymphoma. Int J Occup Med Environ Health 1999;12:135-42.

44 Rego MAV, Sousa CSC, Kato M, et al. Non-Hodgkin's lymphomas and organic solvents. J Occup Environ Med 2002;44:874-81.

45 International Agency for Research on Cancer. IARC monographs on the evaluation of the carcinogenic risk of chemicals to humans. Vol 28. The rubber industry. Lyon: IARC 1982.

46 Rinsky RA, Hornung RW, Silver SR, et al. Benzene exposure and hematopoietic mortality: a long-term epidemiologic risk assessment. Am J Ind Med 2002;42:474-80.
47 Straif K, Weiland SK, Werner B, et al. Workplace risk factors for cancer in the German rubber industry: part 2. Mortality from non-respiratory cancers. Occup Environ Med 1998;55:325-32.

48 Kauppinen T, Toikkanen J, Pukkala E. From cross-tabulations to multipurpose information systems: a new job-exposure matrix. Am J Ind Med 1998;33:409-17.

49 Dubrow R, Wegman DH. Cancer and occupation in Massachusetts: a death certificate study. Am J Ind Med 1984;6:207-30.

50 Figgs LW, Dosemeci M, Blair A. United States non-Hodgkin's lymphoma surveillance by occupation 1984-9: a twenty four state death certificate study. Am J Ind Med 1995;27:817-35.

51 Schroeder JC, Savitz DA. Lymphoma and multiple myeloma mortality in relation to magnetic field exposure among electric utility workers. Am J Ind Med 1997;32:392-402.

52 Miller AB, To T, Agnew DA, et al. Leukemia following occupational exposure to $60-\mathrm{Hz}$ electric and magnetic fields among Ontario electric utility workers. Am J Epidemiol 1996;144:150-60.

53 Sahl JD, Kelsh MA, Greenland S. Cohort and nested case-control studies of hematopoietic cancers and brain cancer among electric utility workers. Epidemiology 1993;4:104-14.

54 Theriault G, Goldberg M, Miller $A B$, et al. Cancer risks associated with occupational exposure to magnetic fields among electric utility workers in Ontario and Quebec, Canada, and France: 1970-89 [Erratum in comments Am J Epidemiol 1994;139:1053]. Am J Epidemiol 1994;139:550-60.

55 Band PR, Le ND, Fang R, et al. Identification of occupational cancer risks in British Columbia: a population-based case-control study of 769 cases of nonHodgkin's lymphoma analysed by histopathology subtypes. J Occup Environ Med 2004;46:479-89.

56 Floderus B, Törnqvist S, Stenlund C. Incidence of selected cancers in Swedish railway workers, 1961-1979. Cancer Causes Control 1994;5:189-94.

57 Tynes T, Reitan JB, Andersen A. Incidence of cancer among workers in Norwegian hydroelectric power companies. Scand J Work Environ Health 1994;20:339-44.

58 Youngson JH, Clayden AD, Myers A, et al. A case-control study of adult haematological malignancies in relation to overhead powerlines. $\mathrm{Br} J$ Cancer 1991;63:977-85

59 Verkasalo PK, Pukkala E, Kaprio J, et al. Magnetic fields of high voltage power lines and risk of cancer in Finnish adults: nationwide cohort study. BMJ 1996:313:1047-51.

60 Loscher W, Liburdy RP. Animal and cellular studies on carcinogenic effects of low frequency $(50 / 60-\mathrm{Hz})$ magnetic fields. Mutat Res 1998;410:185-220.

61 Hardell L, Holmberg B, Malker H, et al. Exposure to extremely low frequency electromagnetic fields and the risk of malignant diseases: an evaluation of epidemiological and experimental findings. Eur J Cancer Prev 1995;4(supp 1):3-107.

62 Litovitz TA, Krause D, Mullins JM. Effect of coherence time of the applied magnetic field on ornithine decarboxylase activity. Biochem Biophys Res Commun 1991;178:862-5.

63 Phillips JL, Rutledge L, Winters WD. Transferrin binding to two human colon carcinoma cell lines: characterization and effect of $60-\mathrm{Hz}$ electromagnetic fields. Cancer Res 1986:46:239-44.

64 Cantor KP, Sontag JM, Heid MF. Patterns of mortality among plumbers and pipefitters. Am J Ind Med 1986;10:73-89.

65 Michaels D, Zoloth S. Asbestos disease in sheet metal workers: proportional mortality update. Am J Ind Med 1988;13:731-4.

66 Ross R, Nichols P, Wright W, et al. Asbestos exposure and lymphomas of the gastrointestinal tract and oral cavity. Lancet 1982;2:1118-20.

67 Becker N, Berger J, Bolm-Audorff U. Asbestos exposure and malignant lymphomas - a review of the epidemiological literature. Int Arch Occup Environ Health 2001;74:459-69.

68 Selikoff IJ, Hammond EC, Seidman H. Mortality experience of insulation workers in the United States and Canada, 1943.1976. Ann N Y Acad Sci 1979;330:91-116.

69 Raffn E, Lynge E, Juel K, et al. Incidence of cancer and mortality among employees in the asbestos cement industry in Denmark. Br J Ind Med 1989;46:90-6.

70 Bengtsson NO, Hardell L, Eriksson M. Asbestos exposure and malignant lymphoma [letter to the editor]. Lancet 1982;2:1463.

71 Siemiatycki J, ed. Risk factors for cancer in the workplace. CRC Press, Boca Raton, FL, USA 1991

72 Dodson RF, Huang J, Bruce JR. Asbestos content in the lymph nodes of nonoccupationally exposed individuals. Am J Ind Med 2000;37:169-74.

73 Rosenthal GJ, Simeonova P, Corsini E. Asbestos toxicity: an immunologic perspective. Rev Environ Health 1999;14:11-20.

74 Zahm SH, Weisenburger DD, Babbitt PA, et al. A case-control study of non Hodgkin's lymphoma and the herbicide 2,4-dichlorophenoxyacetic acid (2,4 D) in eastern Nebraska. Epidemiology 1990;1:349-56.

75 Nanni O, Amadori D, Lugaresi C, et al. Chronic lymphocytic leukaemias and non-Hodgkin's lymphomas by histological type in farming-animal breeding workers: a population-based case-control study based on a priori exposure matrices. Occup Environ Med 1996;53:652-7.

76 McDuffie HH, Pahwa P, McLaughlin JR. Non-Hodgkin's lymphoma and specific pesticide exposures in men: cross-Canada study of pesticides and health. Cancer Epidemiol Biomark Prev 2001;10:1155-63.

77 DeRoos AJ, Zahm SH, Cantor KP, et al. Integravtive assessment of multiple pesticides as risk factors for non-Hodgkin's lymphoma among men. Occup Environ Med 2003;60:e11.

78 Miligi L, Seniori Costantini A, Bolejack V, et al. Non-Hodgkin's lymphoma, leukemia, and exposures in agriculture: results from the Italian multicenter case-control study. Am J Ind Med 2003;44:627-36. 
79 Baris D, Silverman DT, Brown LM, et al. Occupation, pesticide exposure and risk of multiple myeloma. Scand J Work Environ Health 2004;30:215-22.

80 Eriksson $M$, Karlsson M. Occupation and other environmental factors and multiple myeloma: a population based case-control study. $\mathrm{Br} J$ Ind Med 1992;49:95-103.

81 Demers PA, Vaughan TL, Koepsell, et al. A case-control study of multiple myeloma and occupation. Am J Ind Med 1993;23:629-39.

82 Khuder SA, Mutgi AB. Meta-analyses of multiple myeloma and farming. Am J Ind Med 1997;32:510-16.

83 Nanni O, Falcini F, Buiatti E. Multiple myeloma and work in agriculture: results of a case-control study in Forli, Italy. Cancer Causes Control $2001 ; 9: 277-83$.

84 Zahm SH, Blair A. Pesticides and non-Hodgkin's lymphoma. Cancer Res 1992;52:5485s-5488s.

85 Zahm SH, Ward MH, Blair A. Pesticides and cancer. Occup Med 1997; 12:269-89.

86 Faustini A, Settini L, Pacific R, et al. Immunological changes among farmers exposed to phenoxy herbicides: preliminary observations. Occup Environ Med 1996;53:583-5.
87 Figgs LW, Holland NT, Rothman N, et al. Increased lymphocyte replicative index following 2,4-dichlorophenoxyacetic acid herbicide exposure. Cancer Causes Control 2000;1 1:373-80.

88 Schroeder JC, Olshan AF, Baric R, et al. Agricultural risk factors for $\mathrm{t}(14 ; 18)$ subtypes of non-Hodgkin's lymphoma. Epidemiology 2001;12:701-9.

89 T'Mannetje A, McLean D, Cheng S, et al. Mortality in New Zealand workers exposed to phenoxy herbicides and dioxins. Occup Environ Med 2005:62:34-40.

90 Blair A, Thomas TL. Leukemia among Nebraska farmers: a death certificate study. Am J Epidemiol 1979;110:264-73.

91 Clavel J, Mandereau L, Cordier S, et al. Hairy cell leukaemia, occupation, and smoking. Br J Haematol 1995;91:154-61.

92 Cano MI, Pollan M. Non-Hodgkin's lymphomas and occupation in Sweden. Int Arch Occup Environ Health 2001 ;4:443-9.

93 Fritschi L, Johnson KC, Kliewer EV, et al. The Canadian Cancer Registries Epidemiology Research Group. Animal-related occupations and the risk of leukaemia, myeloma, and non-Hodgkin's lymphoma in Canada. Cancer Causes Control 2002;13:563-71.

94 Brandt L. Exposure to organic solvents and risk of haematological malignancies. Leukemia Research 1992;16:67-70.

\section{$\mathrm{ECHO}$}

\section{Chemical fire drill survives reality check ...this time}

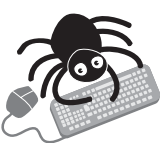

Please visit the Occupational and

Environmental Medicine website [www. occenvmed. com] for a link to the full text of this article. chemical incident at a plastics factory has put to the test official UK guidance on how $\triangle$ to deal with nearby residents. A partial evacuation during a fire lasting 48 hours in a - plastics factory adjoining a large residential area in southwest England afforded researchers the chance to compare for the first time health outcomes between evacuees in the first six hours and residents sheltering at home during the emergency.

In this incident the results of the cross sectional study upheld the guidance, which is for residents to shelter at home. Health outcomes were better for those who stayed indoors: they had significantly fewer mean symptom scores, though the difference lessened with time. The main risk factors contributing to becoming a case (having $\geqslant 4$ symptoms) were evacuation (odds ratio (OR) 2.5) and direct exposure to smoke for more than two hours at the time (OR 2.0).

Health outcomes were assessed by a postal questionnaire based on existing models in London and Wales, which was sent to all residents in the vicinity-472 evacuees and 1278 who remained indoors. Response rate was 63\% overall: 27\% (299) for evacuees and 73\% (797) for sheltering residents.

Official guidance relies on mathematical models of likely scenarios after incidents at storage sites or in the plant releasing a chemical cloud for 30 minutes, but the consequences of exposure to low cumulative amounts of irritant gases in people with health compromised by, for example, asthma and chronic lung disease need to be studied.

However, staying indoors may not be best if toxic irritant gases are inhaled in large amounts over longer time, contends one public health expert. Toxic pneumonitis and even death can result, and even short exposure may trigger airways dysfunction syndrome. In the incident described, complications of asthma and other respiratory diseases were few, and environmental sampling 12 hours after the fire started detected only 1 ppm hydrogen chloride $100 \mathrm{~m}$ downwind within the smoke plume; other irritant gases were undetectable.

Temporary evacuation may be called for depending on management of the fire, materials involved, wind and weather forecasts, and local topography. It should always be considered, ideally with advice from the public health response team, in chemical fires, which can last for days. More epidemiological studies and good information on exposure are essential to test the validity of the guidance in such circumstances

A Kinra S, et al. BMJ 2005; 330:1471-1474.

\ Baxter PJ, et al. BMJ 2005;330:1474-1475. 